\title{
"Applying the CAMEL model to assess performance of commercial banks: empirical evidence from Vietnam"
}

\begin{tabular}{|c|c|}
\hline AUTHORS & $\begin{array}{l}\text { Anh Huu Nguyen (D http://orcid.org/0000-0003-3844-9826 } \\
\text { Hang Thu Nguyen } \\
\text { Huong Thanh Pham }\end{array}$ \\
\hline ARTICLE INFO & $\begin{array}{l}\text { Anh Huu Nguyen, Hang Thu Nguyen and Huong Thanh Pham (2020). Applying } \\
\text { the CAMEL model to assess performance of commercial banks: empirical } \\
\text { evidence from Vietnam. Banks and Bank Systems, 15(2), 177-186. } \\
\text { doi:10.21511/bbs.15(2).2020.16 }\end{array}$ \\
\hline DOI & http://dx.doi.org/10.21511/bbs.15(2).2020.16 \\
\hline RELEASED ON & Tuesday, 23 June 2020 \\
\hline RECEIVED ON & Wednesday, 25 December 2019 \\
\hline ACCEPTED ON & Thursday, 11 June 2020 \\
\hline LICENSE & $\begin{array}{l}(c)) \text { EY } \\
\text { This work is licensed under a Creative Commons Attribution } 4.0 \text { International } \\
\text { License }\end{array}$ \\
\hline JOURNAL & "Banks and Bank Systems" \\
\hline ISSN PRINT & $1816-7403$ \\
\hline ISSN ONLINE & $1991-7074$ \\
\hline PUBLISHER & LLC "Consulting Publishing Company "Business Perspectives" \\
\hline FOUNDER & LLC "Consulting Publishing Company "Business Perspectives" \\
\hline
\end{tabular}

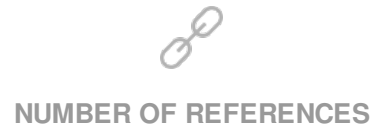

26
NUMBER OF FIGURES

0
NUMBER OF TABLES

6

(C) The author(s) 2023. This publication is an open access article. 


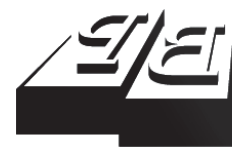

\section{BUSINESS PERSPECTIVES}

LLC "CPC "Business Perspectives" Hryhorii Skovoroda lane, 10, Sumy, 40022, Ukraine www.businessperspectives.org

Received on: $25^{\text {th }}$ of December, 2019 Accepted on: $11^{\text {th }}$ of June, 2020 Published on: $23^{\text {rd }}$ of June, 2020

(C) Anh Huu Nguyen, Hang Thu Nguyen, Huong Thanh Pham, 2020

Anh Huu Nguyen, Ph.D., Associate Professor in Accounting, Dean of School of Accounting and Auditing, School of Accounting and Auditing, Department of Financial Accounting, National Economics University, Vietnam. (Corresponding author)

Hang Thu Nguyen, Master, Ph.D. Candidate, Lecturer, School of Accounting and Auditing, Department of Management Accounting, National Economics University, Vietnam

Huong Thanh Pham, Master, Lecture School of Accounting and Auditing, Department of Accounting Principles, National Economics University Vietnam
Anh Huu Nguyen (Vietnam), Hang Thu Nguyen (Vietnam),

Huong Thanh Pham (Vietnam)

\section{APPLYING THE CAMEL MODEL TO ASSESS PERFORMANCE OF COMMERCIAL BANKS: EMPIRICAL EVIDENCE FROM VIETNAM}

\begin{abstract}
The paper aims to investigate the impact of CAMEL components on the financial performance of commercial banks in Vietnam. Three econometric models are built using four CAMEL's crucial indicators as independent variables (capital adequacy, asset quality, management effectiveness, bank liquidity) and return on assets (ROA), return on equity (ROE), and net interest margin (NIM) as proxies for commercial banks' financial performance - dependent variables. The research sample includes 31 Vietnamese commercial banks over the 6-year period, from 2013 to 2018. The results show a better fit of the fixed effects model (FEM) in terms of the research methodology compared to the ordinary least squares (OLS) and random effects model (REM). It was found that capital adequacy, asset quality, liquidity and management efficiency affect the performance of Vietnamese commercial banks.
\end{abstract}

\section{Keywords}

commercial bank, bank performance, capital adequacy, bank management, net interest rate

\section{JEL Classification G20, G21, G30}

\section{INTRODUCTION}

A banking system is a component of the financial system, which plays an important role in the economic development of countries of the world (Tumin \& Said, 2011). McKinnon (1973), Misra and Aspal (2013) point out the role of the financial system for economic growth and development. Simultaneously, they also emphasize the strong correlation between economic growth and development of the financial system. According to Gupta (2014), the development of an economy largely depends on the deployment and optimal use of resources and, most importantly, on the performance of different sectors of the economy. In particular, the banking sector helps form capital, create money and innovate in addition to facilitating monetary policies. Therefore, careful evaluation and analysis of the operation of banks to ensure a healthy financial system and an effective economy is essential. Misra and Aspal (2013) argued that financial health of a bank is a guarantee not only for depositors, but also of great significance to employees, shareholders and the whole economy of a nation. To evaluate the performance of the banking industry, it is necessary to use efficiency indicators to check the soundness of the activities of an economy. Banks, in particular, face a range of risks that are becoming more and more complex every day (Dang, 2011). It is important to assess the overall effectiveness of banks using the prescribed banking supervision framework, and the CAMEL rating system is an effective monitoring measure. This method was first applied in the United States in 1979, and is currently being used by three U.S. watchdogs - the Federal Reserve System, the Office of Monetary Supervision (OCC) and the Federal 
Deposit Insurance Corporation (FDIC). It has proven to be a useful and effective tool to deal with the 2008 US government financial crisis (Dang, 2011). In Vietnam, commercial banks play a particularly important role in the national economy (Dang, 2011; Nguyen, 2012). Therefore, this paper evaluates performance of the Vietnamese commercial banks using the CAMEL model. The study also assesses the impact of each factor of the CAMEL model on the Vietnamese banks' performance for six years, from 2013 to 2018.

\section{LITERATURE REVIEW AND HYPOTHESES}

\subsection{Bank performance}

The CAMEL system was originally developed and employed by the Federal Financial Institutions Examination Board in 1979 to evaluate the soundness and safety of individual banks in the USA (Dang, 2011). It is applicable to every bank and credit union in the US and is also done outside the United States by various banking supervisors. CAMEL is basically a ratio-based model to evaluate the performance of banks and rank them. In recent years, the framework has become one of the most widely-used approaches to examine the financial stability of commercial banks (Roman \& Sargu, 2013; Rose \& Hudgins, 2010). Following Nimalathasan (2008), Sarker (2005), and Dang (2011), this study applies five ratio categories of the CAMEL framework in this research.

Phan (2013), evaluating Vietnamese commercial banks' performance from 2003 to 2012, suggested a model of the performance of Vietnamese commercial banks, which was formulated using $13 \mathrm{fac}-$ tors, including: Scale of equity; Financial leverage; Minimum capital adequacy ratio; Outstanding debt / Total assets; Bad debt / Total outstanding debt; ROA; ROE; NIM; Operating expense index; Property liquidation rate; Deposit guarantee coefficient; Short-term liquidity coefficient; and Outstanding loans / Deposits.

Jaffar and Manarvi (2011) also used these five CAMEL ratio-based categories to measure and compare Islamic banking performances with others. The two authors stated the CAMEL rating was a standard test to analyze the banking financial performance. Keovongvichith (2012) analyzed financial performance of the banking industry by first examining key indicators of financial devel- opment and then applying the CAMEL system to assess the performance of the banking sector on Laos. The finding showed that there were financial improvements in the asset quality and management in Laotian commercial banks, but there also existed some area of deficiencies, including low capital adequacy and profitability ratio, especially in banks owned by the government. This result is essential in assisting central banks and the government to draw up and implement suitable polices, promoting a healthy and stable banking system.

Ongore and Kusa (2013) have measured the financial performance of commercial banks in Kenya based on the profit target primarily. This study applied CAMEL ratios to examine the financial performance of banks in Kenya. Three indices were used: Return on capital (ROE), return on total assets (ROA), and Net profit difference (NIM). By conducting a survey of five banks in Kenya and using regression models, the authors have pointed out the relationship between the financial performance of banks and the factors affecting financial performance.

CAMEL model is an effective approach for experts and specialists to examine the performances of the banking system (Nguyen, 2011; Douglas, Lont, \& Scott, 2014). The CAMEL model is used to analyze the financial performance at selected banks. Although the research in two countries is different, the results show that the closer the bank's indicators are to the CAMEL model, the higher the financial performance of the bank, and vice versa. Ishaq, Karim, Ahmed, and Zaheer (2016) studied 10 commercial banks operating in Pakistan for seven years (2007-2013). Their results indicated that at the time of the survey, the CAMEL approach to assessing bank performance positively affected bank performance. A study by Zedan and Daas (2017) aimed to assess performance and financial health of Palestinian commercial banks in 2015 using the CAMEL assessment model. Research 
on applying capital adequacy ratio to analyze information about capital adequacy and bad debts for total outstanding loans to analyze asset quality parameters is not a cost to analyze management quality parameters, return on assets and return on equity to explore liquidity management. The research results showed that the financial capacity of Indian commercial banks was influenced by capital size, profitability, liquidity and the quality of assets and management. The study then used the downgrade method to predict the likelihood of commercial banks' future failure.

\subsection{Bank indicators}

\subsubsection{Performance of commercial banks}

To measure the performance of commercial banks, managers and investors are interested in profitability indicators, since profits are the ultimate goal of commercial banks, especially joint stock commercial banks. Profit is also a matter of concern for managers and investors when making strategic decisions. All strategies designed and the activities implemented are aimed at realizing this great goal. There are various ratios used to measure the profitability of a commercial bank. Anggono (2017) and Kumar (2016) suggested that a bank performance variable is represented by two alternative measures, namely ROA and ROE. While in a study by Ongore and Kusa (2013), ROA, ROE and NIM are the main ratios measuring the profitability of a commercial bank.

Return on assets (ROA) is an important indicator of the bank's profitability. This is the average ratio of net profits before tax to total assets (Ongore \& Kusa, 2013; Anggono, 2017). ROA indicates the ability of a bank to generate profit from its total assets. In other words, this indicator shows how profitably a commercial bank uses its resources. The higher the ROA, the more efficiently the resources are used by the bank.

Return on equity (ROE) is another financial indicator representing the relation of the bank profit to its total equity. Bank shareholders will pay much attention to this ratio because it shows the return for their investment. A bank with a high value of ROE is capable of creating an internal cash flow. Therefore, the higher the ROE, the more profit- able the company is in terms of making a profit. Ongore and Kusa (2013) explain that ROE can be measured by the ratio of Net Income to Average Tax / Total Equity. This ratio indicates the profit rate earned from money invested by shareholders, reflecting the bank management's effectiveness in using its capital. Therefore, it can be seen that the better the ROE, the more effective the management of shareholder capital.

Net interest rate (NIM), or net interest margin, is the difference between the bank's income and its expense related to interest such as the difference between the interest income received and the interest expense paid to a lender regarding his/her deposits. Ongore and Kusa (2013, p. 239) defined that "Net interest margin measures the gap between the interest income the bank receives on loans and securities and interest cost of its borrowed funds. It reflects the cost of bank intermediation services and the efficiency of the bank". The higher the net profit rate is, the more profitable and the more stable the bank is. Therefore, the net profit rate is one of the important ratios for measuring the profitability of banks. However, according to Heid (2007), higher net interest rates may reflect more risky lending activities related to loan loss provisions.

\subsubsection{Factors affecting the performance of commercial banks}

Olweny and Shipho (2011) focused on specific industry parameters affecting the performance of commercial banks in Kenya. The CAMEL model is commonly used by scholars to authorize specific elements of a bank (Dang, 2011). CAMEL stands for Capital Adequacy, Asset Quality, Management Efficiency, Earnings and Liquidity. Each indicator is discussed as follows:

Capital adequacy ratio: According to Dang (2011), the capital adequacy ratio is assessed based on capital adequacy ratio (CAR). Sangmi and Tabassum (2010) revealed that the CAR reflected the internal wealth of banks to be able to withstand losses in cases of economic crises. The higher value of this ratio reflects the better resilience ability of a bank to crisis situations.

Asset quality: The quality of the loan portfolio has a direct effect on bank profitability. According 
to Dang (2011), the highest risk that commercial banks face is losses from overdue debts. Therefore, inappropriate lending rates are good credentials for the quality of the asset. Different studies used different types of financial ratios as proxies for bank performance. One of the major concerns of all commercial banks is keeping the number of non-compliant loans at the minimum level. Unsuitable loans will negatively affect bank profitability. Therefore, the more unsuitable loans, the higher the total amount of loans and the better the health of the bank's portfolio. It means that, the lower this ratio, the better the bank operates (Sangmi \& Tabassum, 2010).

Management efficiency: Human management policies, general management policies of an organization, information systems, internal audit and control regimes, strategic and budgetary plans. Books are reviewed separately to reflect the overall quality of management, analyze human resources and the working style of a Board of Directors and Management, as well as to reveal the relationship between two sides. However, some ratios of financial statements act as a proxy for management efficiency. Financial ratio can partly show the bank manager's capability of efficiently organizing bank's resources, maximizing profit, and reducing operating costs. One of these is the ratio of bank operating profit over its total revenue (Ilhomovich, 2009; Sangmi \& Tabassum, 2010). The higher the ratio value is, the more efficient the managers will be in bank operation and income generation.

Liquidity: Liquidity refers to the bank's ability to perform its obligations, primarily to the depositors. Dang (2011) demonstrated that the bank liquidity adequacy was positively related to its profits. Different scholars use different financial ratios for liquidity. The most widely-used ratios reflecting the commercial bank's liquidity position are the ratio of customer deposits to total assets and total customer loan deposits.

There are four factors that were studied by authors such as Ishaq, Karim, Ahmed, and Zaheer (2016), Zedan and Dass (2017), Mohiuddin (2014), and Ongore and Kusa (2013) at the banks of different countries in the world. This study will inherit this result for testing at 31 Vietnamese commercial banks.

\subsection{Research hypotheses}

Based on the literature review above, the paper will examine the following hypotheses:

H1: The size of equity has a positive impact on ROA, ROE, and NIM.

H2: The minimum capital adequacy has a positive impact on ROA, ROE, and NIM.

H3: Financial leverage has an impact on ROA, ROE, and NIM.

H4: The ratio of loans to assets positively affects $R O A, R O E$, and NIM.

H5: The lower the ratio of bad debts to outstanding loans, the higher the ROA, ROE, and NIM.

H6: The higher the operating cost index, the lower the ROA, ROE, and NIM.

H7: Deposit guarantee ratio has a positive impact on ROA, ROE, and NIM.

H8: Short-term liquidity has a positive impact on ROA, ROE, and NIM.

\section{DATA AND METHODOLOGY}

\subsection{Data collection}

This paper collected data from the financial statements, from 2013 to 2018, of Vietnamese commercial banks, with the sample size of 31 banks. In this study, secondary data sources collected from some sources, such as actual data on the system of financial analysis indicators of Vietnamese commercial banks in Vietnam and the information on the banks and financial websites, summarize the results on the financial statements, annual reports, and management reports of commercial banks for 2013-2018, collecting secondary information and data from financial statements of banks, reports of the State Bank, reports of the World Bank, and reports of the banking supervision system for a six-year period from 2013 to 2018. 


\subsection{Research models}

The study used three statistical approaches, including the Ordinary Least Squares (OLS), Fixed Effects Model (FEM), and Random Effects Model (REM) suitable to panel data. After that, the Hausman test was used to determine whether the FEM model or the REM model were suitable for research. After determining the appropriate mod$\mathrm{el}$, the paper removed the excess variable from the model and re-estimated the model to give a regression equation.

Regression models are used in the form of logarithms (LN), independent and dependent variables to homogenize the unit of variables to facilitate the analysis; accordingly, if an independent variable changes by $1 \%$, then a dependent variable will change $c$ \% under the condition of other factors unchanged ( $i=2$ to 9 with the model of ROA and ROE and $i=2$ to 11 with the model of NIM). The model in this research, as in the model of equations (1), (2), and (3), is as follows:

$$
\begin{aligned}
& L N R O A=F C(1)+P C(2) \cdot L N S E+ \\
& +P C(3) \cdot E B T+P C(4) \cdot L N D G C+ \\
& +P C(5) \cdot L N S L C+P(6) \cdot L N L+ \\
& +P C(7) \cdot L N C A R+P C(8) \cdot L N L A R+ \\
& +P C(9) \cdot L N O C+[C X=R] \\
& L N R O E=F C(1)+P C(2) \cdot L N S E+ \\
& +P C(3) \cdot E B T+P C(4) \cdot L N D G C+ \\
& +P C(5) \cdot L N S L C+P(6) \cdot L N L+ \\
& +P C(7) \cdot L N C A R+P C(8) \cdot L N L A R+ \\
& +P C(9) \cdot L N O C+[C X=R], \\
& L N N I M=F C(1)+P C(2) \cdot L N S E+ \\
& +P C(3) \cdot L N N P L+P C(4) \cdot L N O C+ \\
& +P C(5) \cdot L N L R O A+P C(6) L N C A R+ \\
& +P C(7) \cdot L N L+P C(8) \cdot L N D G C+ \\
& +P C(9) \cdot L N S L C+P C(10) \cdot L N R O L D+ \\
& +P C(11) \cdot L N L A R+[C X=R],
\end{aligned}
$$

\begin{tabular}{|c|c|c|c|}
\hline \multicolumn{2}{|c|}{ Independent variables } & \multirow{2}{*}{$\frac{\text { Notation }}{\text { SE }}$} & \multirow[t]{2}{*}{ Measure } \\
\hline \multirow{3}{*}{ 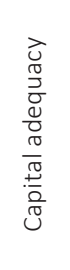 } & Scale of equity & & \\
\hline & $\begin{array}{l}\text { Minimum capital } \\
\text { adequacy ratio (CAR) }\end{array}$ & CAR & $\begin{array}{l}\text { Consolidated } \\
\text { equity capital/ } \\
\text { Total risky } \\
\text { assets }\end{array}$ \\
\hline & $\begin{array}{l}\text { Financial leverage } \\
\text { coefficient (L) }\end{array}$ & L & $\begin{array}{c}\text { Total Liabilities/ } \\
\text { Equity }\end{array}$ \\
\hline \multirow{2}{*}{ 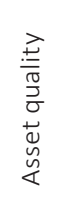 } & $\begin{array}{l}\text { Lending/total assets } \\
\text { ratio }\end{array}$ & LAR & $\begin{array}{c}\text { Credit balance/ } \\
\text { Total assets }\end{array}$ \\
\hline & NPL/total loan ratio & NPL & $\begin{array}{c}\text { Total bad } \\
\text { debt/Total } \\
\text { outstanding } \\
\text { debt }\end{array}$ \\
\hline 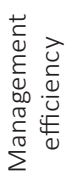 & Operation cost index & $\mathrm{OC}$ & $\begin{array}{c}\text { Operating } \\
\text { expenses/Total } \\
\text { assets }\end{array}$ \\
\hline \multirow{4}{*}{ 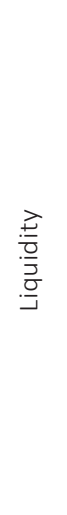 } & $\begin{array}{l}\text { Liquidation ratio of } \\
\text { assets }\end{array}$ & LROA & $\begin{array}{l}\text { Liquidated } \\
\text { assets/Total } \\
\text { assets }\end{array}$ \\
\hline & $\begin{array}{l}\text { Deposit guarantee } \\
\text { coefficient }\end{array}$ & DGC & $\begin{array}{l}\text { Liquidated } \\
\text { assets/Total } \\
\text { deposits }\end{array}$ \\
\hline & $\begin{array}{l}\text { Short-term liquidity } \\
\text { coefficient }\end{array}$ & SLC & $\begin{array}{l}\text { Liquidated } \\
\text { assets/Total } \\
\text { current } \\
\text { liabilities }\end{array}$ \\
\hline & $\begin{array}{l}\text { The ratio of } \\
\text { outstanding loans and } \\
\text { deposits }\end{array}$ & ROLD & $\begin{array}{c}\text { Total } \\
\text { outstanding } \\
\text { loans/Total } \\
\text { deposits }\end{array}$ \\
\hline
\end{tabular}

where $F C(1)$ - free coefficient; $P C(i)(i=211)$ - partial coefficients of the variables affecting the rendering independent youth $C$.

\subsection{Research variables}

\subsubsection{Dependent variables}

Table 1. Dependent variable measurement

\begin{tabular}{l:c|c}
\hline $\begin{array}{c}\text { Dependent } \\
\text { variables }\end{array}$ & Notation & Measure \\
\hline $\begin{array}{l}\text { Return on average } \\
\text { total assets }\end{array}$ & ROA & $\begin{array}{c}\text { Profit after tax/ } \\
\text { Average total assets }\end{array}$ \\
\hdashline $\begin{array}{l}\text { The average rate of } \\
\text { return on equity }\end{array}$ & ROE & $\begin{array}{c}\text { Average profit after tax/ } \\
\text { Equity }\end{array}$ \\
\hdashline $\begin{array}{l}\text { Marginal interest } \\
\text { income }\end{array}$ & NIM & $\begin{array}{c}\text { Net income from interest/ } \\
\text { Average assets }\end{array}$ \\
\hline
\end{tabular}

\subsubsection{Independent variables}

Table 2. Independent variable measurement 


\section{RESULTS AND DISCUSSION}

\subsection{Empirical results}

Model of $R O A$

According to the estimation results, FEM is suitable for a model of factors affecting ROA.

The estimation model is as follows:

$$
\begin{aligned}
& L N R O A=-5.052651+0.596012 \cdot L N S E- \\
& -0.533839 \cdot L N N P L+3.364041 \cdot L N D G C+ \\
& +3.412003 \cdot L N S L C+0.316320 \cdot L N L+ \\
& +1.021402 \cdot L N C A R+0.328083 \cdot L N L A R- \\
& -0.327313 \cdot L N O C+[C X=R] .
\end{aligned}
$$

Thus, the research results show that the bank's ROA may be strongly affected by the short-term payment ratio, deposit guarantee coefficient, and equity safety ratio. Other factors also affect ROA but to a lesser extent.

\section{Model of ROE}

The results show that $\mathrm{P}$-value $=0.3490>0.05$, therefore, the REM model used with the model of factors affecting ROE is appropriate.
Given this result, the study offers the following estimation model with ROE as follows:

$$
\begin{aligned}
& L N R O E=-5.354853+0.949276 \cdot L N S E- \\
& -0.636572 \cdot L N N P L+2.307415 \cdot L N D G C+ \\
& 3.366479 \cdot L N S L C+0.314101 \cdot L N L+ \\
& +0.132779 \cdot L N C A R+0.340314 \cdot L N L A R+ \\
& +0.098419 \cdot L N O C+[C X=R] .
\end{aligned}
$$

\begin{tabular}{|c|c|c|c|c|}
\hline Independent variables & Coefficient & $\begin{array}{c}\text { Probability value } \\
\text { of statistics }\end{array}$ & $\begin{array}{l}\text { Whether the independent variable affects } \\
\text { ROA or not/Dimensional impact }\end{array}$ & $\begin{array}{l}\text { Impact } \\
\text { level }\end{array}$ \\
\hline LNSE & 0.596012 & 0.0000 & Yes / + & 4 \\
\hline LNNPL & -0.533839 & 0.0928 & Yes / - & 8 \\
\hline LNDGC & 3.364041 & 0.0000 & Yes / + & 2 \\
\hline LNSLC & 3.412003 & 0.0000 & Yes / + & 1 \\
\hline LNL & 0.316320 & 0.0223 & Yes / + & 7 \\
\hline LNCAR & 1.021402 & 0.0434 & Yes / + & 3 \\
\hline LNLAR & 0.328083 & 0.0321 & Yes / + & 5 \\
\hline LNOC & -0.327313 & 0.0396 & Yes / - & 6 \\
\hline
\end{tabular}

\begin{tabular}{|c|c|c|c|c|}
\hline Independent variables & Coefficient & Probability value & $\begin{array}{c}\text { Whether the independent variable affects } \\
\text { ROE or not/Dimensional impact }\end{array}$ & $\begin{array}{c}\text { Impact } \\
\text { level }\end{array}$ \\
\hline LNSE & 0.949276 & 0.0000 & Yes / + & 3 \\
\hline LNNPL & -0.636572 & 0.0435 & Yes / - & 4 \\
\hline LNDGC & 2.307415 & 0.0002 & Yes / + & 2 \\
\hline LNSLC & 3.366479 & 0.0000 & Yes $/+$ & 1 \\
\hline LNL & 0.314101 & 0.0238 & Yes / + & 6 \\
\hline LNCAR & 0.132779 & 0.7946 & Not & - \\
\hline LNLAR & 0.340314 & 0.0270 & Yes / + & 5 \\
\hline LNOC & 0.098419 & 0.5259 & Not & - \\
\hline
\end{tabular}

Model of NIM

The regression results show that $\mathrm{P}$-value = $=0.5057>0.05$, so REM model is used with NIM.

The estimation model with NIM is as follows:

$$
\begin{aligned}
& L N N I M=-3.98806+0.267481 \cdot L N S E- \\
& -0.286897 \cdot L N N P L-0.221030 \cdot L N O C+ \\
& +0.889318 \cdot L N L R O A+0.060660 \cdot L N C A R+ \\
& +0.123406 \cdot L N L+0.817760 \cdot L N D G C+ \\
& +0.770909 \cdot L N S L C+0.228410 \cdot L N R+ \\
& +0.140311 \cdot L N L A R+[C X=R] .
\end{aligned}
$$

Table 3. The impact of independent variables on ROA

Table 4. The impact of independent variables on ROE 
Table 5. The impact of independent variables on NIM

\begin{tabular}{|c|c|c|c|c|}
\hline Independent variables & Coefficient & Probability value & $\begin{array}{c}\text { Whether the independent } \\
\text { variable affects NIM or not/ } \\
\text { Dimensional impact }\end{array}$ & Impact level \\
\hline LNSE & 0.267481 & 0.0309 & Yes / + & 5 \\
\hline LNNPL & -0.286897 & 0.0305 & Yes / - & 4 \\
\hline LNOC & -0.221030 & 0.0014 & Yes / - & 6 \\
\hline LNLROA & 0.889318 & 0.0000 & Yes / + & 1 \\
\hline LNCAR & 0.060660 & 0.7729 & Not & - \\
\hline LNL & 0.123406 & 0.0415 & Yes / + & 8 \\
\hline LNDGC & 0.817760 & 0.0018 & Yes / + & 2 \\
\hline LNSLC & 0.770909 & 0.0026 & Yes / + & 3 \\
\hline LNTLDNCV & 0.228410 & 0.6023 & Not & - \\
\hline LNROLD & 0.140311 & 0.0552 & Yes $/+$ & 7 \\
\hline
\end{tabular}

\subsection{Discussion of regression results}

1) According to the results of standardized estimation of the formal theoretical model, the model of factors affecting ROA (Model 1) is dominated by eight factors. These eight factors explain $74.81 \%$ variation of ROA. In particular, the factors of size of equity, deposit guarantee, short-term liquidity, financial leverage, minimum capital adequacy ratio, loan ratio, and the operating expense index affect ROA of commercial banks, while the NPL ratio factor does not affect ROA.

2) Model of factors affecting ROE (Model 2) is governed by eight factors, according to the official estimation results of normalized theoretical models, but these eight factors explain only $64.94 \%$ of ROE variation. In particular, factors such as equity size, deposit guarantee, shortterm liquidity, financial leverage, the bad debt ratio, and the loan ratio affect ROE of commercial banks, while the factors of minimum capital adequacy and operating cost index do not affect ROE.

3) Model of factors affecting NIM (Model 3) is dominated by 10 factors. According to the results of standardized estimation of the formal theoretical model, these 10 factors explain $77.57 \%$ of the ROE variation. In particular, factors of equity size, the deposit guarantee coefficient, the short-term liquidity coefficient, the financial leverage ratio, the bad debt ratio, the loan ratio, and the operating expense index have an impact on NIM, commercial banks is also affected by NIM, while the minimum capital adequacy ratio and the loan outstanding ratio do not affect NIM.

Table 6. Summary of the impact of each factor on the performance of Vietnamese commercial banks

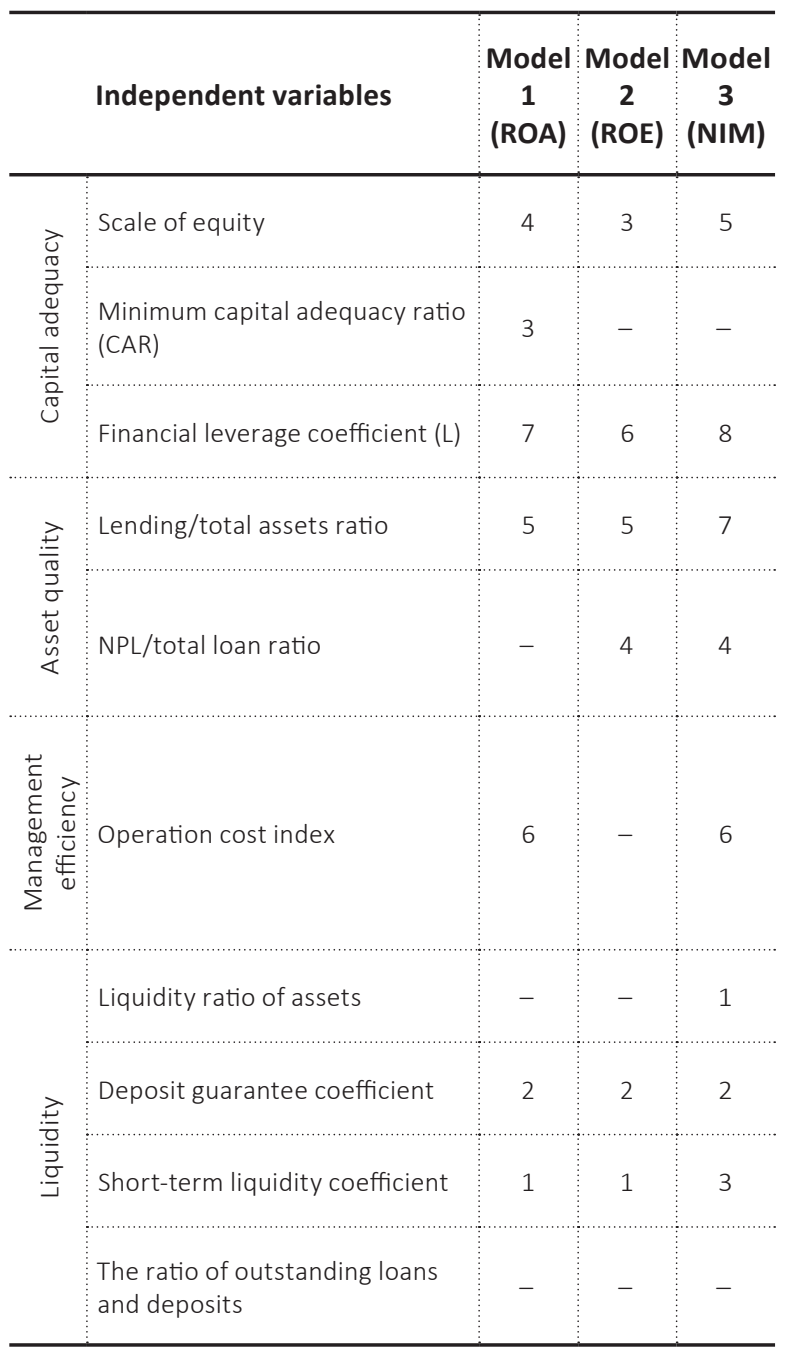




\section{RECOMMENDATIONS}

Based on the results of the study, some key recommendations were proposed aiming to improve the financial performance of Vietnamese commercial banks.

Increased equity capital: In order to increase equity of the banks themselves, especially small and medium ones, banks must take the initiative in implementing the detailed plan to ensure the capital increase in the time period, review bad debts, and evaluate to what extent that bad debt can be converted into equity. When merging with other banks, the common interests of the whole banking system should be in the first place, and not the interests of individual banks, so sooner or later competitors will gain, and at that time will cause even greater damage.

Decreased bad debts: The analysis results, as well as the regression results, show that NPLs tend to increase and this is also a factor that inversely affects the performance of Vietnamese commer- cial banks. The suggestion aims at reducing the amount of bad debts in bank in order to make them healthy in operation, while contributing to the financial restructuring of Vietnam's commercial banking system.

Increased liquidity: As analyzed above, the liquidity of Vietnamese commercial banks gradually decreases over the years, and, according to the regression results, this factor positively affects the performance of the Vietnamese commercial banking system. This means that when the liquidity decreases, the operational efficiency of banks will decrease, and vice versa, so the goal of this solution is to increase the liquidity of Vietnamese commercial banks, thereby boosting their performance.

Increased quality of management: The goal of this solution is to increase the quality of management through the management process of administrators, thereby contributing to improving financial capacity of Vietnamese commercial banks.

\section{CONCLUSION}

The study aims to investigate the impact of CAMEL components on the financial performance of commercial banks in the context of Vietnam. The results confirm the effect of the CAMEL parameters on the performance of Vietnamese commercial banks. The CAMEL model parameters include Capital adequacy, Asset quality, Management efficiency and Liquidity that are taken as independent variables, while financial performance (ROA, ROE, and NIM) is considered as a dependent variable. The sample size for this study is 31 Vietnamese commercial banks. For them, 6-year financial data (from 2013 to 2018) are collected from their annual reports published on their official websites.

This empirical research found that the four categories of the CAMEL model, including capital adequacy, asset quality, management, and liquidity, affect the performance of Vietnamese commercial banks as follows:

Capital adequacy: the size of equity is considered to have the most powerful and positive impact on the performance of Vietnamese commercial banks. This is followed by the leverage ratio and, finally, the minimum capital adequacy ratio. Asset quality: while the bad debt ratio has an opposite effect, the loan/ total asset ratio has a positive effect on the performance of commercial banks. Management quality: the operating expense index has no significant impact on the operational efficiency of banks. This is quite true for Vietnam when banks are not focused on improving management capacity of managers. Earnings measured by ROA, ROE, and NIM are significantly affected by equity size, the deposit guarantee, the short-term liquidity coefficient, and the financial leverage ratio. Liquidity: deposit guarantee ratio and the short-term liquidity ratio have a strong impact on the performance of Vietnamese banks, while the other factors have no or little effect. 


\section{ACKNOWLEDGEMENT}

This research is funded by National Economics University (NEU), Hanoi, Vietnam. The authors thank anonymous referees for their contributions and the NEU for funding this research.

\section{AUTHOR CONTRIBUTIONS}

Conceptualization: Anh Huu Nguyen, Hang Thu Nguyen, Huong Thanh Pham.

Data curation: Hang Thu Nguyen, Huong Thanh Pham.

Formal analysis: Anh Huu Nguyen, Hang Thu Nguyen, Huong Thanh Pham.

Investigation: Anh Huu Nguyen.

Methodology: Anh Huu Nguyen, Hang Thu Nguyen, Huong Thanh Pham.

Resources: Anh Huu Nguyen.

Software: Hang Thu Nguyen, Huong Thanh Pham.

Supervision: Anh Huu Nguyen.

Validation: Anh Huu Nguyen.

Visualization: Hang Thu Nguyen, Huong Thanh Pham.

Writing - original draft: Anh Huu Nguyen, Hang Thu Nguyen, Huong Thanh Pham.

Writing - reviewing \& editing: Anh Huu Nguyen.

\section{REFERENCES}

1. Anggono, H. (2017). The determinant factors of asset and liability management and the bank performance: empirical study on foreign exchange commercial banks in Indonesia from 2008 to 2013. International Journal of Business and Globalization, 19(4), 512-527. https://doi.org/10.1504/ IJBG.2017.087298

2. Dang, U. (2011). The CAMEL rating system in banking supervision: A case study (Degree Thesis). Arcada University of Applied Sciences. Retrieved from https:// www.theseus.fi/bitstream/handle/10024/38344/Dang_Uyen.pdf

3. Douglas, E., Lont, D., \& Scott, T. (2014). Finance company failure in New Zealand during 2006-2009: predictable failures? Journal of Contemporary Accounting and Economics, 10(3), 277-295. https:// doi.org/10.1016/j.jcae.2014.10.002

4. Gupta, CA. R. (2014). An analysis of Indian public sector banks using camel approach. IOSR Journal of Business and Management, 16(1), 94-102. Retrieved from http://iosrjournals.org/iosr-jbm/ papers/Vol16-issue1/Version-4/ L0161494102.pdf
5. Heid, F. (2007). The cyclical effects of the Basel II capital requirements. Journal of Banking and Finance, 31(12), 3885-3900. https://doi. org/10.1016/j.jbankfin.2007.03.004

6. Ilhomovich, S. E. (2009). Factors affecting the performance of foreign banks in Malaysia. (Masters Thesis). Universiti Utara Malaysia. Retrieved from https://docplayer. net/42734713-Factors-affectingthe-performance-of-foreignbanks-in-malaysia-saidov-elyorilhomovich-master-of-science-banking-universiti-utara-malaysia.html

7. Ishaq, A. B., Karim, A., Ahmed, S., \& Zaheer, A. (2016). Evaluating Performance of Commercial Banks in Pakistan: An Application of Camel Model. Journal of Business and Financial Affairs, 5(1), 1-30. https://dx.doi.org/10.4172/21670234.1000169

8. Jaffar, M., \& Manarvi, I. (2011). Performance comparison of Islamic and conventional banks in Pakistan. Global Journal of Management and Business Research, 11(1), 59-66. Retrieved from https:// globaljournals.org/GJMBR_Volume11/7_Performance_comparison_of_Islamic_and_Conventional_ banks_in_Pakistan.pdf
9. Keovongvichith, P. (2012). An analysis of the recent financial performance of the Laotian banking sector during 2005-2010. International Journal of Economics and Finance, 4(4), 148-162. https:// doi.org/10.5539/ijef.v4n4p148

10. Kumar, V. (2016). Evaluating the financial performance and financial stability of national commercial banks in the UAE. International Journal of Business and Globalisation, 16(2), 109127. https://doi.org/10.1504/ IJBG.2016.074477

11. McKinnon, R. (1973). Money and capital in economic development. Brookings Institution, Washington DC, USA.

12. Misra, S. K., \& Aspal, P. K. (2013). A camel model analysis of state bank group. World Journal of Social Sciences, 3(4), 36-55. Retrieved from https://eclass.aueb. gr/modules/document/file.php/ LOXR307/paper_CAMEL_model. pdf

13. Mohiuddin, G. (2014). Use of camel model: a study on financial performance of selected commercial banks in Bangladesh. Universal Journal of Accounting and Finance, 2(5), 151-160. 
Retrieved from http://www. hrpub.org/journals/article_info. php?aid=2095

14. Nguyen, N. P. (2011). An overview of the financial situation in Vietnamese joint stock commercial banks. Journal of Economics \& Development, 3(1), 77-86. Retrieved from http://jed.neu.edu.vn/

15. Nguyen, T. H. (2012). Analysis of financial structure in commercial banks. Journal of Economics \& Forecasting, 5(1) 102-110. Retrieved from http://kinhtevadubao.vn/ danh-sach/214/tap-chi-kinh-te-vadu-bao.html

16. Nimalathasan, B. (2008). A comparative study of financial performance of banking sector in Bangladesh - an application of CAMELS rating system. Economic and Administrative Series, 2(1), 141152. Retrieved from https://papers. ssrn.com/sol3/papers.cfm?abstract_ $\mathrm{id}=2117189$

17. Olweny, T., \& Shipho, T. M. (2011). Effects of banking sectoral factors on the profitability of commercial banks in Kenya. Economics and Finance Review, 1(5), 1-30. Retrieved from https:// www.semanticscholar.org/paper/ EFFECTS-OF-BANKING-SECTORAL-FACTORS-ON-THEOF-BANKS-Olweny-Shipho/d2b- 0d261c3ccb484cb1faaab0b1b43ed$62 \mathrm{f} 16 \mathrm{e} 6 \mathrm{e}$

18. Ongore, V. O., \& Kusa, G. B. (2013). Determinants of Financial Performance of Commercial Banks in Kenya. International Journal of Economics and Financial Issues, 3(1), 237-252. Retrieved from https://www.econjournals. com/index.php/ijefi/article/ view/334/pdf

19. Phan, H.N.T. (2013). Financial capacity of Vietnamese commercial banks. ProQuest Digital Dissertation (AAT 6234020).

20. Roman, A., \& Şargu, A. C. (2013). Analysing the financial soundness of the commercial banks in Romania: an approach based on the camels framework. Procedia Economics and Finance, 6(1), 703-712. https://doi.org/10.1016/ S2212-5671(13)00192-5

21. Rose, P., \& Hudgins, S. (2010). Bank management and financial services. McGraw-Hill/Irwin.

22. Sangmi, M., \& Tabassum, N. (2010). Analyzing Financial Performance of Commercial Banks in India: Application of CAMEL Model. Pakistan Journal Commercial Social Sciences, 4(1), 40-55. Retrieved from https://www.econstor.eu/bitstream/10419/187999/1/pjcss028. pdf

23. Sarker, A. (2005). CAMEL rating system in the context of Islamic banking: a proposed 'S' for Sariah framework. Journal of Islamic Economics and Finance, 1(1), 7884. Retrieved from https://ibtra. com/pdf/journal/v2_n2_article4. pdf

24. Sundararajan, V., Enoch, C., San José, A., Hilbers, P., Krueger, R., Moretti, M., \& Slack, G. (2002). Financial Soundness Indicators: Analytical Aspects and Country Practice (IMF Occasional Paper No. 212). International Monetary Fund. Retrieved from https:// rbidocs.rbi.org.in/rdocs/content/ PDFs/75443.pdf

25. Tumin, M. H., \& Said, R. M (2011). Performance and financial ratios of commercial banks in Malaysia and China. International Review of Business Research Papers, 7(2), 157-169. https://doi. org/10.2139/ssrn.1663612

26. Zedan, K., \& Daas, G. (2017). Palestinian Banks Analysis Using CAMEL Model. International Journal of Economics and Financial Issues, 7(1), 351-357. Retrieved from http://www.econjournals. com/index.php/ijefi/article/ view/3238/pdf 